\title{
At finde frem til det uforudsigelige \\ - Etnografiske fortællinger om elevers kreative processer i skolen
}

\author{
Margit Saltofte
}

\begin{abstract}
Artiklen eksemplificerer feltarbejdsmetoders betydning for at undersøge og begrebsliggøre kreativitet i skolekontekster (Saltofte 2010, 2012a). Antropologiske feltarbejdsmetoder er designet til at leve sig ind i andres oplevelse af verden og dermed kunne tilgodese uforudsigelighed. Metodedesignet må, for at undersøge og beskrive kreative processer, indebære mulighed for at studere såvel interaktionelle processer som strukturelle forhold. Feltarbejde præsenteres som en erfaringsproces, der indebærer at finde begreber for det uforudsigelige. "Kreative processer" analyseres ud fra indsigt i såvel feltens eksplicitte betegnelse og implicitte anerkendelse. Der fremanalyseres en forskel mellem, hvad der ved projektarbejde anerkendes af skolen som institution, og hvad der anerkendes blandt elever. Det institutionelt anerkendte kreative fremstår i kraft af feltarbejdet, som noget elever kan opnå ved at tilføje produkter fra skolens musisk kreative fag.
\end{abstract}

Keywords: Kreative processer, etnografi, feltarbejde, metodisk fleksibilitet

Please cite this article as:

Saltofte, M. (2013). At finde frem til det uforudsigelige: Etnografiske fortællinger om elevers kreative processer i skolen. Qualitative Studies, 4(1): 72-85.

\section{På feltarbejde på friskole}

Formålet med denne artikel er at undersøge, hvordan erfaringer ved antropologisk feltarbejde kan føre til at skabe tematisk begrebsliggørelse af hverdagspraksis. Temaet for det konkrete feltarbejde er "kreativitet" i skolen, hvorfor der i artiklen ligeledes fremkommer pointer om, hvordan kreative processer i skolen er positionerede og situeret, afhængig af relationer og institutionelle rammer. Kreative processer, betragter jeg, som uventede og socialt betydningslagte interaktioner. At opleve såvel overraskelse som betydningslæggelse, hvor og hvordan den forekommer, kan opnås ved at være til stede som deltagerobservatør i en specifik kontekst. Dermed kan man få indblik i de interaktioner, som er overraskende og betydningsfulde for aktørerne - i denne undersøgelse vil det sige: eleverne. I mit ph.d. projekt (Saltofte 2010) valgte jeg på baggrund af to pilotundersøgelser af tværfagligt projektarbejde på folkeskoler at foretage fire måneders feltarbejde i 9. klasse på Friskolen ${ }^{1}$, som en empirisk tilgang til at undersøge og begrebsliggøre kreative processer.

Tre uger inde i feltarbejdet på Friskolen. Jeg befinder mig i fælles området, hvor 9. klasses eleverne opholder sig i forbindelse med deres projektarbejde. Jeg samler op på noter omkring, at eleverne ikke har produceret så meget til projektet i de forgangne lektioner. Min store frustration lige nu er dog; "hvad skal jeg kigge efter?!" Jeg har en fornemmelse af, at det der "kreativitets-begreb" blokerer. Det er som om, mine observationer ikke rigtig får fat i noget, at det kun er overfladen. Hvem og hvad skal jeg beskrive? Det kunne være; hvad der engagerer dem i deres arbejde, men der er ikke så meget synlig energi eller engagement at styre efter. Måske er det en følelse, en fornemmelse af fortættet

\footnotetext{
${ }^{1}$ Friskolen er anonymiseret og optræder dermed udelukkende som "Friskolen”, ligesom lærere og elevers navne er opdigtede.
} 
stemning, engagement - men jeg har i al fald ikke 'fået øje på det' i denne kontekst og vil meget nødigt definere det mere håndfast, for derefter at gå ud at få øje på det. (Feltnoter 26/11 2007)

Jackson beskriver, at feltarbejde på samme tid kan være lystfyldt og engagerende, som frustrerende og kaotisk (Jackson 1990), hvilket kommer frem af ovenstående feltnoter. De konkrete feltnoter kan betegnes som "metodologiske notater" (Tjørnhøj-Thomsen \& Whyte 2007), der har til formål at overveje, hvordan metoderne kan tilpasses, så det i højere grad 'besvarer' undersøgelsesspørgsmålet. Tjørnhøj-Thomsen \& Whyte (2007) sondrer mellem feltarbejderens deskriptive notater (eller observationsnotater), metodologiske notater samt analytiske (eller teoretiske) notater.

Min forståelse af "kreativitet" forud for feltarbejdet var, at det udgjorde noget 'anderledes', der dog i nogen grad havde afsæt i noget velkendt. Anderledesheden forventede jeg kunne komme til udtryk i elevers fordybelse og engagement i interesseområder på tværs af fag, eller på kant af skolekonteksten. I min bagvedliggende forventning til forekomster af kreative processer i en skolekontekst, var vægtningen i højere grad på skabelsesprocesser end på produkter (i bred forstand) som nyskabende. Desuden havde jeg på forhånd foretaget et valg om at fokusere på kreativitetens sociale og interrelationelle processer og udtryk. Dette var overvejelser, der lå til grund for at vælge tværfagligt projektarbejde til at studere kreative processer empirisk. Det velkendte (i det konkrete tilfælde: faglige tilgange og viden) forestillede jeg mig var afsæt, byggesten for det anderledes og nyskabende: Projektarbejdets ramme, forventede jeg, potentielt foranledigede et engagement for elever i at gøre noget andet og at have større indflydelse på emne og arbejdsform.

Der kan i projektrammen opstå nye fagkombinationer, mere selvstændigt arbejde og mulighed for fordybelse. Tværfagligt projektarbejde er karakteriseret ved at være noget andet end almindelig undervisning såvel i arbejdsform, lærerens strukturering og rolle, som forventninger til elevernes læreprocesser og produkter. Skolen og rammerne for feltarbejdet var valgt for at kunne observere såvel almindelig undervisning, som tværfagligt projektarbejde.

På samme måde som det er vanskeligt at undersøge "kulturs" implicitte aspekter ved at spørge om det (Hasse 2002), var det uhensigtsmæssigt i feltarbejdet at spørge direkte til "kreativitet". Min hensigt var at opnå et datamateriale til at skabe fortællinger om kreative processer i en konkret skoleproces. Min analyse af potentielt kreative processer fandt sted som en analytisk pendulering mellem at fremskrive mønstre ud fra empiriske data, refleksion over mine erfaringer og erkendelser på baggrund af feltarbejdet, samt læse mig ind på feltet kreative læreprocesser. Min tilgang til dette feltarbejde er eksplorativt, at studere projektarbejde som 'det anderledes' i skolekonteksten, og dermed potentielt kunne danne afsæt for at beskrive kreative processer, hvor de opstod og hvordan de fremstod. Dette søgte jeg at indeholde i undersøgelsesdesignet ved at rette opmærksomheden mod såvel eksplicitte, som hvad der fremstod for mig som implicitte kreative udtryksformer og praksis.

\section{Feltarbejde tilpasset undersøgelsesfeltet}

I min forskningsproces bevægede jeg mig hen til at betragte kreativitet som afhængig af sociale anerkendelseskriterier i sociokulturelle fællesskaber, af både formaliseret og mere uformaliseret art. Erkendelsesprocessen, der mundede ud i den analytiske pointe om social anerkendelses betydning, startede med at følge og være til stede med elever, såvel når de havde undervisning eller undervisningsaktiviteter, som når de holdt pauser sammen. Strategien med at følge først 
og fremmest eleverne havde sin grund $\mathrm{i}$ en forestilling og forventning om at finde ind til kreative processer ud fra et elevperspektiv. Min tilgang til at forstå kreativitet ud fra et livsverdens perspektiv kommer til udtryk $\mathrm{i}$ valg af observations fokus, analysen af mine empiriske data samt teoretiske begreber om kreativitet som situeret i en sociokulturel kontekst (Saltofte 2010). Hermed bliver undersøgelse af "kreativitet" med en antropologisk tilgang ikke en foreskrivelse af, hvad der bør eller kunne foregå, men en detaljerig beskrivelse af, hvad jeg har observeret, og hvordan det bidrager til min metodiske tilgang til fænomenet "kreativitet".

Feltarbejde udgør antropologiens overordnede metodologiske strategier, mens deltagerobservation beskriver en særlig måde, antropologer forholder sig og undersøger på i felten. Feltarbejdsprocessen kan betegnes som kaotisk, men ligeledes en åben og åbnende proces, hvor man sætter sig selv på spil i rollen som den uvidende og inkompetente i forhold til den praksis, der undersøges. Man kan imidlertid ikke løsrive sig fra den positionering, man også tilskrives i felten. Ligeledes oplever deltagerobservatøren misforståelser samt at 'begå fejl' i forhold til at indgå i den konkrete kontekst. Ved sådanne fejl ligger et potentiale for 'at støde ind $i^{\prime}$ uventede forståelser. Såkaldte fejl eller ikke intenderede handlinger indeholder i feltarbejde et stort læringspotentiale for feltarbejderen. Feltarbejde og deltagerobservation påvirker såvel forskeren som de mennesker, der udgør undersøgelsesfeltet, og dermed undersøgelsen og skabelsen af viden. Disse vilkår stiller krav om refleksivitet, dvs. en kritisk opmærksomhed på og synliggørelse af de valg og vilkår, der har indvirkning på det empiriske materiale og forskningens konklusioner. (Tjørnhøj-Thomsen \& Whyte 2007, p. 88) I mit feltarbejde blev mine indgående erfaringer med at have været elev, samt være forælder til børn i danske skoler som et væsentligt blindt punkt. Jeg valgte derfor at observere projektarbejde på en international skole i Holland, for dermed at få 'forstyrret' min forforståelse af, hvad projektarbejde er og kan være. At sætte mig selv i en læreproces i forhold til, hvad tværfagligt projektarbejde også kan være, indebar en fornyet refleksion over, hvad der har betydning for, at kreative processer kan opstå og anerkendes i en skolekontekst.

Feltarbejderen søger at opnå indsigt i social og kulturel praksis i felten for optimalt set at "forstå det de andre forstår" (Dalsgård 2003). Det, der adskiller feltarbejdet som metode fra mere strukturerede undersøgelsesmetoder, er, at man ganske ofte ikke kan spørge direkte, men må finde veje ind til at skabe sig forståelse, en orientering om et oplevet fænomen. Som feltarbejder erfarer og erkender man noget uventet, som ikke ville være fremkommet uden at være i den tætte kontakt med felten og de aktører, feltafgrænsningen indebærer. Etnografiske data udspringer af væren - til stede og med andre - og af viljen til at undergå forandring snarere end trangen til at beherske (Dalsgård 2003, p. 333). Det anses som såvel et vilkår som en kvalitet ved feltarbejdet, at det ikke altid er svar på det spørgsmål, man har stillet, der kommer ud af den enkelte udøvende antropologs søgen. Det er meget ofte noget uventet, som ikke ville være fremkommet uden at være i den tætte kontakt med felten og de aktører feltbegrebet omkredser.

... hvis man i forvejen alt for nøje har bestemt sig for, hvad man vil finde ud af, er der en vis risiko for, at man kun vil finde det man netop leder efter, og så kunne man lige så godt være blevet hjemme. (Ovesen 1989, p. 90)

Samspillet mellem felt og feltarbejderen, i såvel feltarbejdet som i analysen, udgør en erfaringsproces for feltarbejderen. Felten for den empiriske undersøgelse er defineret af undersøgelsesspørgsmålet, der løbende afgrænses af undersøgerens observationer af og interaktioner med informanter i felten. 
Betydningen af at være til stede $\mathrm{i}$ form af feltarbejde, kan karakteriseres som en kontekstualisering, hvor man lever sig ind med alle sine sanser, hvilket lægger sig tæt op ad fænomenologiens erfaringsprocesser. At kunne sætte sig dels $i$ en andens sted og dels se en situation med en udenforståendes øjne betegnes indenfor fænomenologisk filosofi som at sætte sin forforståelse i parentes. Deltagerobservation kan som undersøgelsesform og erkendelsesproces tage udgangspunkt $\mathrm{i}$ at forstå en livsverdensdimension. Et væsentligt træk ved deltagerobservationen er netop dens lighed med hverdagslivets værensformer, hvorfor metoden knytter sig til fænomenologisk erkendelsesforståelse. Den antropologiske praksis er kendetegnet ved de samme grundtræk som menneskelivet i øvrigt. Dobbeltbevægelsen af distance og nærhed betegner Gammeltoft (2003) som selve "menneskelivets princip" med reference til filosoffen Buber.

Oplevelser og erfaringer ved deltagerobservation indskriver sig i en livsverden, således som fænomenologien forstår og tilnærmer sig denne. Antropologiske erkendelsesprocesser orienterer sig mod, at aktørers livsverden og dermed antropologisk vidensskabelse også viser sig i "sprækkerne mellem ordene" (Hastrup 2003, p. 102). I det følgende afsnit præsenteres, hvordan min analytiske forståelse af kreativitet i en konkret sociokulturel kontekst, erkendes og begrebsliggøres.

\section{Kreativitet som et kontekstuelt fænomen}

Forandringsprocesser, og dermed kreativitet, kan betegnes som et alment kulturelt princip, der følger alt socialt liv. Sawyer beskriver i sin gennemgang af kontekstuelle tilgange til kreativitet den antropologiske indflydelse på denne tilgang som:

Cultural change always involves creativity. But this kind of creativity is very different from fine art painting or musical performance because it's creativity of everyday life. In cultural creativity, novelty is a transformation of cultural practices and appropriateness is the value to a community. (Saywer 2006, p. 139)

Antropologiske tilgange kan bidrage til at betragte "kreativititet", ikke som noget der 'er' - men derimod noget, der betydningslægges og frembringes sociokulturelt. Kreativitet er positioneret, og ikke et neutralt og naturalistisk begreb, der kan løsrives fra f.eks. en institutionel kontekst. Hvem der udøver og besidder definitionsmagten i forhold til at identificere kreativitet, er i høj grad kultur- og kontekstafhængigt. Foranlediget af mine erfaringer fra feltarbejdet med forskellige sociale rum og dermed; forskellige udtryks- og anerkendelsesformer, har jeg til min analyse anvendt Sawyers (2006) begreber "novelty" og "appropriateness", til at fremanalysere kreative processer. Desuden har jeg tilføjet såvel 'overraskelse' som 'betydningslæggelse' for at påpege det interaktionelle aspekt i kreative processer (Saltofte 2010). "Kreativitet" i skolen er noget, der afhænger af strukturelle forhold (Saltofte 2012a), men også noget der åbner mulighed for, at elever skaber noget nyt ved deres konkrete handlinger. Dette nye fører sjældent til institutionel omskabelse, men kan have indflydelse på kulturen i elevfællesskaber - såvel i forhold til hvilke udtryksformer, der indgår som fællesskabets repertoire. Deltagerobservation kan være en måde, hvorpå man som forsker kan få indsigt i, hvilke underliggende kriterier der hersker for at anerkende det "nye" som "passende" i en konkret sociokulturel kontekst.

Fortællingen er del af måden at formidle den empiriske analyse, og fremstår som en form velegnet til at beskrive konkrete kreative processer. Den gennemgående tråd i udvælgelsen af data fra mine feltnoter til brug i fortællingerne, er, at de udgør "thick descriptions" (Geertz 
1973); betydningslagte erkendelser om kreative processer, som de fremtrådte for mig ved mit feltarbejde på Friskolen.

Impressionist tales present the doing of fieldwork rather than simply the doer or the done. (...) Tales often initiate an analysis of the nature of cultural understanding and the fieldworker's role as a student. (Van Maanen 1988, p. 102)

Impressionist tales adskiller sig fra de to andre typer etnografiske fortælleformer Van Maanen (1988) oplister; "confessional tales" og "realist tales", hvilke beskriver henholdsvis 'the doer' og 'the done'. De tre former kan dermed sammenlignes med henholdsvis "metodologiske notater" og "deskriptive notater", hvorimod "impressionist tales" ligger tættere op ad "analytiske notater" (Tjørnhøj-Thomsen \& Whyte 2006)2. I denne artikel vil en impressionistiske etnografiske fremstilling blive suppleret af en "realist tale" tilgang. Hermed betones såvel erfaringer med kreativitets sociokulturelle rum³, som analytiske erkendelser herved, som en læreproces. 'The doing' af feltarbejde bliver dermed en indgang til at præsentere, hvordan kreativitet som en sociokulturel proces konkret kan komme til udtryk. På samme tid viser fremstillingen eksempler på, hvordan feltarbejderen qua sin lære- og erkendelsesproces udgør et 'instrument' til begrebsdannelse.

"Hvor gives der i skolen plads til kreativitet som et udtryk for noget, man ikke på forhånd til fulde har defineret?"

Dette spørgsmål formet som "analytiske notater", stillede jeg mig forud for feltarbejdet. Det fremstod ganske markant ved mine pilotundersøgelser af projektopgaven i to folkeskoler, at elevernes udfoldelsesrum og engagement $i$ at forfølge egne interesser $i$ høj grad gled i baggrunden under projektarbejder. Anerkendt kreativitet var i projektarbejder hovedsagelig afgrænset i skolens musisk kreative fag, og tiltænkt at bygge ovenpå en faglighed indenfor de mere 'boglige fag' (Saltofte 2012a). Et af de tydeligste udtryk for, hvordan kreativitet blev understøttet og ekspliciteret var i, at der på Friskolen var en forventning om, at eleverne også præsenterede et "kreativt produkt". Forventningen til et kreativt produkt var, at det skulle udbygge eller perspektiver den mere 'boglige' fremstilling. Betegnelsen "det kreative produkt" indgik som en hverdagsbetegnelse blandt lærere og elever for den perspektivering, man ved musisk kreative frembringelser kunne tilføje sit projekt.

Problemformuleringsarbejdet i starten af projektarbejdet fremstår langt mindre lyst- og glædesfuld end arbejdsprocesser omkring 'det kreative produkt'. 'Det kreative produkt' sikrer i praksis en hel del mere selvstændig råderet for eleverne. De bliver her slet ikke i samme omfang 'rettet på'. Der foregår i lærerelev relationen i højere grad en 'spørgen-ind-til' og 'lytten til ideer' fra lærerens side. Selvstyret er tydeligere, læreren giver mere råd til håndtering af materialer, i forhold til selve udførelsen gives nogle gange ideer, men ellers er rammesætningen mere på tid, sted og respektfuld omgang med materialer. (Feltnoter 10/12 07)

\footnotetext{
2 "Impressionist tales" kan imidlertid i sin mest veludførte form, som f.eks. Geertz (1973) i skriveform ligeledes sammenlignes med litteratur. (Van Maanen 1988)

3 'Rum' forstås her som såvel en forekomst $\mathrm{i}$ tid, sted som aktørernes interaktionelle handlinger i relation hertil.
} 
I udarbejdelsen af kreative produkter viste sig noget af det engagement og en fordybelse hos eleverne, som jeg i starten af feltarbejdet på Friskolen efterspurgte, for at kunne beskrive kreative processer empirisk. ${ }^{4}$ Det strukturelle niveau i anerkendelse af kreativitet i skolen blev imidlertid ligeledes synligt i kraft af den institutionelle praksis betegnelse "det kreative produkt". Produkterne blev understøttet fagligt og rammesat som arbejdsproces ud fra, hvilke musisk kreative fag og fagfaciliteter, der var på skolen. Det var dermed et afgrænset og noget begrænset repertoire, der blev anerkendt som et "passende" (Sawyer 2006) såkaldt "kreativt produkt".

Refleksionerne fra feltarbejdet kan betegnes som analytiske, men får såvel metodiske som analytiske konsekvenser for den måde, jeg vægter at lægge mit fokus i mine observationer og løbende analyser af disse. I de følgende "analytiske notater" (Tjørnhøj-Thomsen \& Whyte 2007) reflekterer jeg, på baggrund af mine feltarbejdserfaringer, over, hvilke kreative udtryksformer, der kan anerkendes ved projektarbejdet på de tre undersøgte skoler.

I hver af de tre 9. klasser jeg har været deltagerobservatør i, har der været mindst en gruppe eller person, der har skilt sig ud ved at vise en særegen og meget anderledes præsentation. Hvordan kan det være, at det ikke er videre udbredt, at projekt formatet ikke i videre udstrækning bliver set og brugt som mulighed for at 'folde sig ud'? (Feltnoter 13/12 2007)

Refleksionerne over mere strukturelle sammenhænge i skolekonteksterne, foretog jeg mig under præsentationer af det første projektarbejde, jeg undersøgte på Friskolen. I dette feltarbejde undersøgte jeg ud fra et elevperspektiv konkrete interaktioner, i udgangspunktet $\mathrm{i}$ relation til tværfagligt projektarbejde. Min analytiske opmærksomhed og metodiske design bredte sig imidlertid ud til også at dække interaktioner udenfor projektarbejde, for ligeledes at kunne indeholde de af elever så betydningslagte "mellemrumszoner"(Saltofte 2012b). ${ }^{5}$ Det vil jeg eksemplificere og sætte i forhold til, hvordan min løbende analyse af erfaringer og hændelser i feltarbejdet fører til en teoretisk begribelse af kreative processer. Tematisk er præsentationen bygget op ud fra en oplevelse i feltarbejdet af en elevs ikke institutionelt anerkendte kreativitet.

\section{Etnografiske fortællinger om den skjulte kreativitet}

I det forudgående afsnit har det været behandlet, hvordan kreativitet kan undersøges som et interaktionelt og strukturelt fænomen i en konkret kontekst. Der findes i skolekonteksten institutionelle måder at understøtte og anerkende kreative processer på. Ved at være deltagerobservatør fik jeg ligeledes indsigt i mere implicitte, og for mig uventede, kriterier for kreativitet. I det følgende vil der blive stillet skarpt på konkrete "kreative processer" som de fortolkes og beskrives af feltarbejderen. Ved at være til stede sammen med eleverne - til tider også i frikvarterer, er jeg på dette tidspunkt af feltarbejdet ved at bliver opmærksom på alt det kreative, der foregår udenfor almindelig undervisning og projektarbejde.

På Friskolen har lærerne netop givet nogle få instrukser til det videre arbejde i det langvarige projekt ${ }^{6}$. Nogle elever har begivet sig hen til computere eller

\footnotetext{
${ }_{5}^{4}$ Se feltnoter præsenteret på nærværendes artikels første side.

5 "Mellemrumszone" interaktioner og positioner eksemplificeres i det følgende.

${ }^{6}$ Ved mit feltarbejde på Friskolen undersøgte jeg to tværfaglige projektforløb i 9. klasse. Det første strakte sig over en længere periode, med nogle ugentlige skemalagte projektarbejdsmoduler. Det andet
} 
andre steder i det fælles rum, et par elever sidder tilbage og snakker sammen. Her befinder jeg mig ligeledes. Jeg læner mig frem mod Vibeke og spørger, hvad hun laver projekt om. Hun foreslår, at vi går et andet sted hen og taler om det.

Da vi har bevæget os hen i en afsides del af fællesområdet, fortæller hun om, hvilke dårlige oplevelser, hun har bag sig fra en tidligere skole. De indebærer, at hun ikke kan koncentrere sig om at lave projekt. Derfor har lærerne accepteret, at hun arbejder med noget selvvalgt i den periode, hvor der er projektforløb.

Jeg spørger hende, om hun var med til den fælles temauge for hele skolen, der har fundet sted en måned forinden.

Vibeke (lyser op):"Ja. Jeg var med til at male det der store maleri derovre."

Hun peger på en bred frise, der dækker det meste af den ene væg i dette fællesområde. Hun udpeger tre figurer på denne frise, som hun har malet.

Jeg: "Har du tegnet meget?"

Vibeke: "Jeg tegner også derhjemme. Jeg har lavet nogle plakater. Vil du se?"

Hun tager sin mobiltelefon frem og viser mig billeder af to plakater, hun har malet. Jeg kigger på dem. Det er figurer, der er blandinger af mennesker og dyr, der giver mig associationer til et fantasy univers. Hun fortæller, at hun finder motiverne på nettet og sidder med computeren på gulvet foran sig, mens hun tegner.

Vibeke (smiler): "Nogle gang kan jeg få helt ondt i knæene! (af at sidde så længe)"

Senere på dagen på lærerværelset taler jeg med læreren Finn. Her fortæller jeg ham om, at jeg har set nogle af Vibekes billeder. Han var ikke klar over, at hun havde denne interesse. (Feltnoter 18/12 2007)

De ovenstående "deskriptive notater" - fremstillet som en "realist tale" - giver feltarbejderen afsæt for "analytiske" og "metodiske notater", der præsenteres som en form for "impressionist tale" her nedenfor (Tjørnhøj-Thomsen \& Whyte 2006, Van Maanen 1988).

"Hvordan gives der plads til det dybtfølte, det skabende der ikke skal demonstrere et fagligt emne i skolen? Er dette, og må det være: løsrevet fra undervisningen som sådan, også fra projektarbejde i og med, at det er temaet, der styrer og der derfor må være en klar faglig rammesætning? Det kommer jeg til at tænke på i forbindelse med Vibekes tegninger og den glæde det tydeligvis giver hende at lave dem. Det er det modsatte af krav og frustrationen over ikke at kunne forstå kravene, og dermed ikke kunne leve op til dem - hvilket igen betyder manglende anerkendelse."

Mine refleksioner i disse "analytiske notater" over, hvilke kreative processer og udtryksformer skolen lagde op til, skrev jeg om foranlediget af samtalen med Vibeke. Skoleinstitutionen og dermed lærernes, ofte implicitte, definitionsmagt af "det passende" (Sawyer 2006), viser sig i dette tilfælde at have stor betydning for at en udtryksform som maleri, opleves som isoleret til enkelte "kreative" fag og emnearbejder. (Saltofte 2012a)

var den ugelange lovpligtige projektopgave, som jeg også undersøgte i pilotundersøgelser på tofolkeskoler forud for feltarbejdet. 
Ved præsentationerne af 9. klasses projektopgaver viser det sig, at Finn har foreslået Vibeke at tage nogle af sine tegninger og malerier med. Han har hemed handlet på, at jeg som deltagerobservatør har fortalt ham om Vibekes interesse for at tegne.

Vibeke går og hænger sine malerier op i klasseværelset i en pause i projektpræsentationerne. Efterhånden som elever, der kommer ind i klassen, får øje på dem, er der flere der overrasket spørger, om hun har malet dem.

Charlotte: "Hold kxft, hoor er du god til at male!"

Vibeke siger noget lavt (jeg ikke kan høre).

Charlotte (smiler og siger ironisk som et understatement): "Årh, det er da ingenting. Det er bare noget fingermaling, jeg har lavet."

Vibeke (smiler): "Fingermaling!". (Griner lidt)

Luke giver sig til at forhandle om at købe et af malerierne.

To elever står og kigger på et billede, og spørger om det forestiller en fugl i et træ. Dette bekræfter Vibeke. Andre spørger til en af hendes fantasy-inspirerede figurer, hun begynder at forklare om dette billede. Der er efterhånden en del elever rundt om Vibeke. Nogle spørger, hvordan hun gør, og om hun selv finder på det. Der står nogle elever og taler om, hvad de vil koste at købe, og hvilke de bedst kan lide.

Elevernes reaktion på Vibekes præsentation af sine billeder er overraskelse, der særlig kommer til udtryk som en anerkendende betydningstillæggelse. Hendes produkter såvel som iscenesættelsen af præsentationen udgør dermed såvel noget nyt som passende for eleverne.

\section{Lærerne søger den vante struktur}

Efter Vibekes præsentation af malerierne træder lærerne ind i den velkendte rolle. De søger efter begrundelser for produkterne. Lærerne lader ikke deres oplevelse af at se den ellers stille og tilbagetrukne elev vise sig fra en helt anden side, skinne igennem.

FREDE: "Når du maler dem, hoad bruger du så?"

Vibeke: "Acrylmaling". (Hun leverer svaret hurtigt og kigger mod resten af klassen for at modtage flere spørgsmål og kommentarer.)

FREDE: "Jeg mener, er det i tuber eller bøtter?"

Vibeke: "I tuber eller...det er i bøtter. Sådan nogle bøtter." (Synes at blive usikker over spørgsmålet.)

FINN: "Kan du fortælle noget om, hvorfor du har valgt de motiver, du har og dit valg af farver måske?" 
Vibeke (tøver og synes at have svært ved at finde ord): "Jamen altså, det er nok fordi, det er nemmere at lave de lange streger $i$ kroppene $i$ stedet for så mange detaljer. Jeg kan godt lide at tegne kroppe."

\section{Christian (elev): "Er det halvt dyr og halvt menneske?"}

Det bekræfter Vibeke og spørger dernæst, om de også vil se hendes tegninger, hvilket der svares bekræftende på. Hun bladrer igennem tegningerne, mens hun kort præsenterer dem. Ved et af dem kommenterer hun:

"Det her synes jeg er rigtig flot, da der også er skygger på."

En elev siger "ja" med eftertryk, ellers er der helt stille.

Da hun har vist alle de medbragte tegninger, er dette et tegn til, at præsentationen er slut. Der klappes endnu engang, rigtig højt.

Ud fra de ovenstående observationer fremstillet $\mathrm{i}$ analytiske notater, er det min hensigt at præsentere, hvordan Vibeke viser en anden form for engagement end det projektfagligt anerkendte i skolekonteksten. Hun er eksempel på en elev, der bliver bragt frem ved at kunne dykke ned i sin interesse og vise den frem. Hvilket jeg, forud for feltarbejdet, forventede ville forekomme ved tværfagligt projektarbejde, som præsenteret i artiklens start. Det skete ikke i særlig høj grad - Vibeke udgør i den forbindelse en undtagelse. Ud fra lærernes manglende anerkendelse af hendes produkter og præsentation, bliver det imidlertid tydeligt for mig, hvorfor det ikke forekommer så ofte (Saltofte 2012a).

Hvis nogen af eleverne havde kritik eller ikke syntes om Vibekes billeder, var det ikke noget, der blev udtrykt. De gav udelukkende udtryk for beundring og overraskelse. Det stod i modsætning til lærernes interesse i at få forklaring på 'hvordan' og begrundelser for 'hvorfor'. Læreren Frede ville have detailteknisk indsigt; hvilken maling hun brugte. Læreren Finn brugte en faglig betegnelse for hendes malerier "meget ekspressive" og ville vide; hvad hun ville udtrykke med dem samt om de havde relevans for hendes emne.

Vibeke giver udtryk for, hvad hun godt kan lide at tegne, hvilket ikke er et vanligt argument for at begrunde et fagligt valg i projektarbejde. Vibeke træder frem med stolthed over og engagement i sine malerier. Hun kan ikke forklare sine valg i den projektfaglige diskurs, de synes meget implicitte for hende, da hun heller ikke tidligere har præsenteret sine udtryk i en skolefaglig kontekst. Uden 'forklaring' kan kreative produkter ikke vurderes som relevante og dermed anerkendes af lærerene. Kreative produkter tillægges ikke betydning i sig selv på et 9 . klasses niveau, de værdsættes i projektarbejde udelukkende, hvis de kan udbygge projektets pointer, uden at overskride strukturen (Saltofte 2012a). Jeg har heraf analytisk opstillet et modsætningsforhold, der kan beskrives som "institutionaliseret kreativitet", der anerkendes af lærere, og "mellemrumszone kreativitet", der udelukkende anerkendes af andre elever. (Saltofte 2010)

\section{Elevernes interne anerkendelse}

At modtage anerkendelse for nye udtryk indebærer, at nogen mere eller mindre eksplicit tilkendegiver at udtrykket kan tillægges værdi. I sagens natur indebærer det, at ikke alt kan anerkendes. Nogle udtryk og statements vil tillægges mindre betydning eller måske vurderes som upassende indenfor den sociokulturelle kontekst, det finder sted i. Blandt eleverne var der 
en helt særlig fortættet stemning under Vibekes præsentation; der blev udtrykt overraskelse over, at hun kunne noget sådant. Stemningen strakte sig ind i pausen, hvor der blev uddelt knus til Vibeke og elever samlede sig om hende for at tage hendes tegninger i nærmere øjesyn. De udtrykte deres beundring ved bl.a. at spørge om de kunne købe nogle af dem samt ved at de udpege, hvilke de synes var særlig flotte. Elevernes handlinger i dette tidslige mellemrum , viser at "mellemrumszone" interaktioner i skolekonteksten ikke er mindre betydningslagte af eleverne end de, der eksplicit og implicit vurderes i "klasserumszoner" (Saltofte 2012a, 2012b). Der lægges et betydeligt engagement $i$ at være del af og opnå anerkendelse i det sociale rum af andre elever.

Den tydeligste forskel i positionering i skolekonteksten er: lærer-elev. Forskellen i roller kommer til udtryk som en forskel i den viden og erfaring de skaber. Her finder jeg, at det mest markante skel viste sig i frikvarterer, hvor lærerne begiver sig til lærerværelser, mens eleverne her har en 'lomme' i tid og rum, der ikke er institutionelt defineret af, at de forventes at foretage sig 'noget bestemt'. I "mellemrumszoner" er interaktionerne og selve tilstedeværelsen i den konkrete situation af mere frivillig art. Lærerne er sjældent til stede, og der foregår dermed ikke en vurdering af den art, som er relateret til karaktergivning og lignende. Den vurdering der foregår, er mere implicit og af social karakter, relateret til anerkendelseskriterier og positioneringer i den sociale kontekst med andre elever. Denne type anerkendelse er imidlertid konstituerende for elevers oplevelse af at høre til - i forståelsen at ens ytringer genkendes og anerkendes som betydningsfulde af de andre elever - en oplevelse, der har indflydelse på oplevelsen af at gå i skole.

Interaktionerne ved Vibekes præsentation viser, hvordan nogle kreative produkter tillægges stor betydning af eleverne, samt at selve overraskelsesmomentet fører til en oplevelse blandt eleverne af noget såvel "nyt" som måske "passende". Det passende udgør her en sociokulturelt funderet anerkendelsesproces, hvor Vibeke kommer til syne som skabende individ. De andre elevers reaktion viser anerkendelse af hendes frembringelser, såvel som af den situation hun skaber Vibeke bliver hermed 'sat på landkortet' blandt de andre elever. Vibekes talent og engagement er også overraskende for projektlærerne. De ved ikke, at hun er god til at tegne. Ved malingen af frisen til emnearbejdet, var det skolens billedkunstlærer, der vejledte. Vibekes præsentation af sine - indtil da ukendte - tegninger og malerier beskrevet i ovenstående uddrag fra "deskriptive notater" (Tjørnhøj-Thomsen \& Whyte 2007), gav et indblik i, hvordan lærerne og elevernes anerkendelseskriterier adskilte sig fra hinanden. Der viste sig, bl.a. i dette tilfælde, at være parallelle 'diskurser' i skolekonteksten. En institutionel, der refererede til en skolefaglig forståelse, og en form oppebåret af elevers umiddelbare engagement $\mathrm{i}$ hinandens interesser, udtryk og statements - der oftest kom til udtryk udenfor undervisningen. Elevers respons på Vibekes præsentation, viste sig ganske anderledes, og indikerede andre kriterier for anerkendelse af, hvad der er "passende" (Sawyer 2006) nyskabende.

Da betydningslæggelse af potentielt kreative udtryk kommer til syne i interaktionelle processer, vil det have betydning for undersøgelsen, hvordan man er til stede som undersøger og opnår kendskab såvel til strukturer og positioner som til aktørers konkrete praksis.

\section{Ruten til forståelse af positionerede kreative processer}

Ovenfor har jeg argumenteret for, at en etnografisk undersøgelse og antropologisk analyse kan undersøge og eksemplificere kreative processer, ved at vise eksempler på forbindelsen mellem feltarbejderens erkendelsesproces og metodiske og analytiske implikationer som følge heraf. Processen med at 'designe' et feltarbejde - såvel i metoder, som i analytisk og teoretisk 
perspektiv - viser en metodemæssig fleksibilitet. Det er dog ikke ensbetydende med at metode og analyse ikke fra starten har en substans. Den forforståelse undersøgelsesperspektivet bygger på, er såvel af erfaringsmæssig karakter (faglig og personlig), som baseret på teori og videnskabelig viden. Metodologiske problemstillinger relateret til antropologisk feltarbejde, har sit afsæt $i$, at deltagerobservation og interviews ikke er afgrænselige og strukturerende teknikker, der kan anvendes på samme måde i enhver kvalitativ undersøgelse. Det er et væsentligt vilkår ved deltagerobservationsmetoden, at der sker en udvikling i ens undersøgelsesspørgsmål, hvilket foregår i det, Wadel (1991) betegner som en runddans mellem teori, metode og empiri. Den antropologiske analyse relaterer sig helt grundlæggende til at forstå, hvad de empiriske data kan udsige og hvilken form for begrebsliggørelse, data og erfaringer i felten kan føre frem til. En sådan 'runddans' i min feltarbejdserfaring afstedkom, at jeg i teoriudviklingen løbende har arbejdet med at forstå "mellemrumszonens" (Saltofte 2012a, 2012b) anderledeshed, og hvordan anderledesheden i skolekonteksten kom til udtryk i, hvad der blev anerkendt som betydningsfuldt af forskellige aktører.

Det er ved feltarbejdet på Friskolen, at det idealtypiske relations- og situationsbestemte begrebspar "klasserumszone" og "mellemrumszone" udvikles, og forståelsen af kreativitet som kontekstuel og udtryk for sociokulturelle processer og strukturer på samme tid eksemplificeres og fremanalyseres (Saltofte 2012a). Wadel betegner de fleste feltarbejder som rodede, i betydningen at det på ingen måde er ualmindeligt at justere og ændre teori og metode op til flere gange under et feltarbejde. Han betegner det imidlertid som et "kreativt rod". Det kreative i feltarbejdet består i, at det ikke bare er en metodisk praksis, men ligeledes en "teoretisk praksis". I betegnelsen teoretisk praksis ligger, at feltarbejdet indebærer mere end dataindsamling, det indebærer i høj grad dataudvikling. Dataudviklingen sker parallelt med at feltarbejderen udvikler nye begreber, hypoteser og teorier (Wadel 1991, p. 23). Her er det dog $\mathrm{i}$ mindre grad selve parallellen mellem fænomenet 'kreative processer' og 'feltarbejdserkendelsesprocesser', der er mest relevant at påpege. At feltarbejdsmetoder og særlig penduleringsprocessen i analysen kan betegnes som "kreativ" (Wadel 1991, Hastrup 2004b), skyldes mulighed for at begrebsdanne ved at skabe eller anvende teorier, der er 'passende' for de fremanalyserede pointer og omvendt.

Min antropologiske tilgang til kreativitet indebærer, at fokus dels er på sociokulturelle processer, og dels på diversitet som et alment menneskeligt vilkår, der giver sig udtryk kulturelt. Kreativitet indebærer et vist element af overraskelse - en rystelse, hvor man som modtager eller observatør bliver usikker på, hvad der nu følger. Teoridannelsen skal derfor på en og samme gang være afgrænsende og fleksibel i forhold til at indramme de processer, der viser sig relevante for at kunne beskrive potentiel og konkret kreativitet. På den anden side må den teoretiske ramme være fleksibel i den forstand, at den kan udvides eller eventuelt helt erstattes, hvis analysen af empirien foreskriver en anden retning. Det viste sig under mit feltarbejde at være mindst lige så interessant at være vidne til den kreativitet, der fandt sted udenfor eller på kanten af projektarbejdets aktiviteter. Valg af feltarbejdsmetoder åbner mulighed for at skabe deres rammesætning (design) efter, hvad der 'passer til' de fremanalyserede pointer. Det vilkår må, på den anden side, siges ikke at være specifikt for antropologisk feltarbejde, men at være et væsentligt kriterium for undersøgelsesmetoder generelt.

Hastrup \& Hervik (1994) søger at skitsere ruten fra social erfaring ved antropologisk feltarbejde, der gør etnografen i stand til at opnå viden, ikke kun om 'kultur' og 'samfund', men ligeledes om den proces der fører til at kultur og samfund transformeres (Hastrup \& Hervik 1994, p. 2). 'Ruten' til at forstå kreativitet i den specifikke institutionelle kontekst indebar at gå fra 
udelukkende at undersøge tværfagligt projektarbejde, til også at analysere konkrete lærer-elev relationer og deres institutionelle forankring i tid og rum.

I Friskolens "mellemrumszoner" herskede der andre samværsformer, et andet repertoire og dermed andre anerkendelseskriterier, end i "klasserumszoner" (Saltofte 2010, 2012a). Det var desuden andre elever, der var iøjnefaldende aktører, end ved kreativitet anerkendt i undervisningskonteksten (Saltofte 2012a, 2012b). De sociale erfaringer ved feltarbejdets deltagerobservation og interview har ført til en "rute" (Hastrup \& Hervik 1994), der kan fremskrives som en metalæring af at være til stede i felten. Begrebet "mellemrumszones" opståen kan, så at sige ledes tilbage retrospektivt til feltarbejdes løbende analytiske refleksioner. 'Ruten' til at betragte kreativitet som 'sociale rum' i tid og sted, startede med at følge og være til stede med elever. Mit fokus blev rettet mod organiseringen i interaktioner blandt 9. klasses elever, og hvordan improvisationer på baggrund af f.eks. stand up comedy, tv-reklamer og at spille musik var fremtrædende i mellemrumszoner. Den form for 'væren i verden', som jeg erfarer blandt 9. klasses eleverne på Friskolen, bl.a. når de interagerede og improviserede med kammerater, adskiller sig markant fra elevernes tilstedeværelsesformer i undervisningens sociale og positionerede 'rum'. Den viden, der i skolens 'sociale rum' anerkendes som kreativ, er en situeret kulturel viden relateret til kontekst og positioneringer. Situeret kulturel viden tillader mennesker at begå sig i konkrete kontekster (Hastrup 2004a).

Otto var en elev på Friskolen, der var tilbageholdende og fremstod noget anonym i faglige sammenhænge. Han var imidlertid en fremtrædende aktør blandt en stor gruppe drenge, hvilket særlig kom til udtryk i "mellemrumszoner". Han citerede brudstykker af stand-up citater og bryggede videre på dem, parodierede ret præcist episoder fra skolen - ofte til stor morskab og anerkendelse blandt de andre drenge. Hans frembringelser betydningslægges dermed socialt i interaktionen med drengene som "nye" og overraskende, såvel som "passende". Udtryksformerne florerer som en af de mest fremtrædende i drengenes interne interaktioner. Han gen- og omskaber dermed på samme tid et produkt, som deres oplevelse af at være et fællesskab og være elever i den konkrete skole. Da jeg i et interview spørger Otto, om han bruger udtryksformer som stand-up i projektarbejdet, ligner han et spørgsmålstegn. Det betragter han tydeligvis ikke som en mulighed. Hans reaktion er overraskende for mig, og fører til at jeg 'støder ind i' et kulturelt vilkår i skolekonteksten, som jeg ikke kunne have spurgt ind til, uden først at have foretaget deltagerobservationer. Hans overraskelse, tolker jeg, er udtryk for at hans performance i "mellemrumszoner", såvel i form som indhold, hører til i en anden sociokulturel kontekst og hviler på andre anerkendelseskriterier og modtagere.

De institutionelt uformelle sammenhænge i skolekonteksten giver anderledes viden med relevans for forståelse af kreativitet som et kontekstuelt begreb. Min viden om betydningen og den stadige skabelse af og i "mellemrumszoner" kunne ikke være fremkommet ved f.eks. at foretage interviews, da det forudsatte tilstedeværelse at få kendskab til denne form for implicitte erfaringer. Det betydningsfulde fremstår i hverdagspraksis ofte som en tavs viden for aktørerne. Denne "sociale erfaring" (Hastrup \& Hervik 1994) som deltagerobservatør udgjorde en betydningsfuld erkendelsesproces i forhold til at komme nærmere fænomenet 'kreativitet' i den kontekstuelle sammenhæng. At være til stede som feltarbejder i en uvidende position er ikke kun noget, man 'må overkomme'.Feltarbejdet udgør en position med et potentiale som læreproces til at få indsigt i sociokulturelt funderet og sanktionerede fænomener som f.eks. "kreativitet". I kraft af mit feltarbejde kunne jeg fremanalysere forskellige kreativitetsformer, der adskilte sig i forhold til; samværsformer, repertoire og positionering af aktører. "Kreativitet" har jeg derfor analytisk kunne fremsætte som et sociokulturelt fænomen, som har 
afsæt $\mathrm{i}$ allerede eksisterende viden inden for en konkret sociokulturel kontekst. Det er inden for de sociale og kulturelle fællesskaber, at potentielt kreative udtryk tillægges betydning.

\section{Antropologisk undersøgelse som indsigt i diversitet af kreative processer}

Jeg har sammenlignet kreative processer, som jeg har erfaret dem ved antropologisk feltarbejde i skolekontekster med de processer, man i etnografisk feltarbejde må placere sig i for at skaffe viden. En viden, som man ikke på forhånd helt har kunnet forestille sig, om end ens forforståelse og mulige position sætter visse rammer. Den nye viden opnår jeg ved at tilstræbe at være uvidende, som del af sin antropologiske læreproces. Jeg har undersøgt den situerede læreproces, der opstår ved, at man fra en position som nytilkommen til en konkret organisation eller institution, så at sige åbner behovet for at skabe orientering. Mit valg af undersøgelsesstrategi er sket løbende, da jeg f.eks. ikke havde forudset, hvilken betydning elevernes "mellemrumszoner" havde (Saltofte 2012a). De kreative interaktioner, der finder sted i yderkanten af skolen som social og kulturel kontekst, er vanskelige at 'finde frem til' med andre metoder end deltagerobservation.

Kreative processer er for aktørerne i høj grad ikke ekspliciteret og ofte ikke betydningslagt i termer af "kreativitet". Der er hermed tale om, at feltarbejdet som metode besidder sin styrke i potentielt at kunne finde ind til det uforudsete og uudtalte, det kulturelt implicitte. En læreproces, der indebærer at kunne få indblik i tavs og implicit viden, der tillægges betydning af aktørerne i den eller de konkrete sociokulturelle kontekster, kreative processer studeres indenfor. "Kreativitet" er dermed ikke udelukkende en social og kulturel eksplicit praksis, man som feltarbejder kan spørge ind til. Den må som andre sociale processer erfares eller opleves for at kunne begribes. Empiriske data fra feltarbejdet har ført til en konkret og ekspliciteret begrebslig forbindelse mellem kreativitet og institutionel anerkendelse af, hvad der betegnes som kreativt og af hvem.

Feltarbejdets eksplorative tilgang har imidlertid også en begrænsning. Den antropologiske analyses svaghed kan være at have begreber, der modsvarer de sociale og kulturelle processer (her: kreative processer) - og ikke kun fremskriver strukturer og mønstre. En sociokulturel kreativitetsteori synes dermed velvalgt til at undersøge kreative processer set $\mathrm{i}$ forhold til konteksten. Den kan dog med fordel tilføres et interaktionelt perspektiv, således at det kan afdække konkrete processer - hvilket der er præsenteret eksempler på i denne artikel.

\section{Litteratur}

Dalsgård, A. L. (2003). Teksten - kunsten at fortælle. In K. Hastrup (ed.). Ind i verden: en grundbog i antropologisk metode. København: Hans Reitzels Forlag

Gammeltoft, T. (2003). Intimiteten - forholdet til den anden. In Hastrup (ed.). Ind i verden: en grundbog i antropologisk metode. København: Hans Reitzels Forlag

Geertz, C. (1973). The Interpretation of Cultures. New York: Basic Books

Hastrup, K. (2003). Sproget - den praktiske forståelse. In Hastrup (ed.). Ind i verden: en grundbog i antropologisk metode. København: Hans Reitzels Forlag

Hastrup, K. (2004a). Refleksion - vidensbegreber og videnskab. In Hastrup, K. (ed.). Viden om verden: en grundbog i antropologisk analyse. København: Hans Reitzels Forlag

Hastrup, K. (2004b). Kultur - Det fleksible fællesskab. Aarhus: Aarhus Universitetsforlag 
Hastrup, K. \& Hervik, P. (1994). Introduction. In Hastrup \& Hervik (ed.) (1994). Social Experience and Anthropological Knowledge. London: Routledge

Jackson, J. E. (1990) Deja Entendu: The Liminal Qualities of Anthropological Fieldnotes. Journal of Contemporary Ethnography, 19: 1

Ovesen, J. (1989). Gæsten og storpolitikken: dialog med Pashia-folket i Afganistan. In Hastrup, K. \& Ramløv, K. (ed). Feltarbejde: oplevelse og metode i etnografien. København: Akademisk Forlag

Saltofte, M. (2010). Kreativitet i klasserum og mellemrum - en etnografisk undersøgelse af projektopgaven i 9. klasser i forhold til kreative processer som skabelse af og ved situerede kulturelle vidensformer. Upubliceret Ph.d. afhandling. Institut for Læring og Filosofi, Aalborg Universitet

Saltofte, M. (2012a). Anerkendelse af kreativitet i skolen - men hvilken slags? In Paulsen, M. \& Klausen, S. H. Innovation og læring. Aalborg: Aalborg Universitets Forlag

Saltofte, M. (2012b). Når Ingenting Sker - drenges improvisationer i skolens mellemrum. Jordens Folk, 4: 4-9.

Sawyer, K. R. (2006). Explaining Creativity: the Science of Human Innovation. Oxford: Oxford University Press

Tjørnhøj-Thomsen, T. \& Whyte, S. (2007). Feltarbejde, etnografisk metode. In Vallgårda \& Koch (ed.). Forskningsmetoder i folkesundhedsvidenskab. København: Munksgaard

Van Maanen, J. (1988). Tales of the Field: on Writing Ethnography. Chicago: University of Chicago Press

Wadel, C. (1991). Feltarbeid i egen kultur. Flekkefjord: Seek a/s

\section{Forfatter}

Margit Saltofte er adjunkt på Institut for Læring og Filosofi, Aalborg Universitet. Email: margit@learning.aau.dk 